\title{
Molecular and Phylogenetic Analysis of Mycoplasma gallisepticum in Haryana, India
}

\author{
Vaishali $^{1^{*}}$, Davinder Singh ${ }^{2}$ and Renu Gupta ${ }^{1}$ \\ ${ }^{1}$ Department of Veterinary Public Health and Epidemiology, LUVAS, Hisar, India \\ ${ }^{2}$ Extension Specialist, Directorate of Extension Education, LUVAS, Hisar, India \\ *Corresponding author
}

\section{Keywords}

Mycoplasma gallisepticum, Molecular and Phylogenetic Analysis

Article Info

Accepted:

22 December 2019

Available Online:

20 January 2020

\section{A B S T R A C T}

Avian mycoplasmosis is responsible for heavy economic loses to the poultry industry in India. It results from a complex interaction of various factors like viral, bacterial and housing conditions. Mycoplasma gallisepticum (MG) belongs to class Mollicutes is small in size, lacks bacterial cell wall with minimum genetic information. It is the principle pathogenic agent causing Chronic Respiratory disease (CRD) in chickens and infectious sinusitis in Turkeys and has a worldwide distribution. The objective of this study was molecular detection of Mycoplasma gallisepticum in poultry with respiratory affections in Haryana (India). 100 tissue samples including trachea, lungs and air sacs were collected and pooled from 100 different poultry flocks in different districts of Haryana. The samples were screened by Polymerase chain reaction (PCR) for Mycoplasma gallisepticum. A prevalence of 16\% (16/100) was seen for Mycoplasma gallisepticum by using $16 \mathrm{~S}$ to $23 \mathrm{~S}$ rRNA primer. PCR can be used for a simple and quick way to identify Mycoplasma gallisepticum from field samples.

\section{Introduction}

The most common causes of high mortality in poultry birds is due to respiratory distress, heat stress and E.coli infections. Avian mycoplasmosis is one of the most prevalent poultry problem affecting the industry economically. The Respiratory disease complex has contributed to heavy economic loses and it comprises cluster of factors responsible for the spread of disease and affecting mortality among the birds comprising of bird handling, viral, mycoplasma and various environmental factors like temperature, high ammonia concentration and others. Mycoplasma gallisepticum is the principle pathogenic agent causing Chronic Respiratory diseases and causes heavy mortality. Dodd in 1995 gave the first accurate description of Mycoplasma gallisepticum in turkey and it was known as epizootic penumoenteritis (Dodd 1995). Existence of disease related with M. gallisepticum were depicted in both 
chicken and turkey and the harmful impacts were decreased with proper and synchronised management on the farms. Within intensive poultry farming, infection by CRD is found in association with avian influenza, Newcastle disease, colibacillosis and infectious bronchitis and further leads to more severe problems (Stipkovits et al., 2012).It is the principle pathogenic agent causing Chronic Respiratory disease (CRD) in chickens and infectious sinusitis in Turkeys and has a worldwide distribution (Li et al., 2010).

Mycoplasma gallisepticum infections vary from asymptomatic to severe symptoms like reduced feed efficiency, reduced egg production and decreased growth rate (Sarkar et al., 2005). It is characterized by coughing, nasal discharge, rales and severe lesionson air sacs commonly air sacculitis (Tomar et al., 2017). Grossly, thickened air sacs with caseous or mucous exudate, catarrhal inflammation in bronchi, trachea and sinuses, fibrinous perihepatitis, interstitial pneumonia and adhesive pericarditis (Yamamoto, 1991; Charlton et al., 1996). There has been a horizontal and vertical transmission documentation (Kumaragurubaran et al., 2018).

\section{Material and Methods}

\section{Sample Collection}

A total of 100 samples were collected from seven different districts of Haryana. Bhiwani $(n=2)$, Hisar $(n=9)$, Jhajjar $(n=19)$, Jind $(n=20)$, Karnal $(n=20)$, Panipat $(n=23)$ and Sonepat $(n=7)$. SonepatThe samples were collected from October 2018 to Feburary 2019. Trachea, lungs and air sacs were collected from poultry flocks and were pooled, and together known as "sample".

\section{DNA Extraction}

DNA was extracted from directly from tissues collected from various poultry farms using DNA extraction mini kit (QIAmp mini kit) as recommended by the manufacturer.

\section{Gene specific PCR}

PCR was carried out on 100 pooled tissue samples from various poultry flocks. 16 to 23 $\mathrm{S}$ rRNA PCR specific to Mycoplasma gallisepticum was per the protocols described by Ravivet al., 2007). The primer selected for M. gallisepticum for 16 to $23 \mathrm{~S}$ rRNA was; F5' GTAGGGCCGGT GATTGGAGTTA3' and R-5' CCCGTAGCATTTCGCAGGTTTG 3' and the size of the amplified product was $810 \mathrm{bp}$. The positive control used for Mycoplasma gallisepticum was S-6 serotype antigen (Salsbury laboratories, U.K.).

The protocol of Ravivet al. (2007) was used with certain modifications. The initial denaturation was achieved at $94{ }^{\circ} \mathrm{C}$ for 10 min with Sapphire fast PCR- hot start master mix. It was further followed by 35 cycles of denaturation at $94{ }^{\circ} \mathrm{C}$ for $30 \mathrm{sec}$, annealing at $62^{\circ} \mathrm{C}$ for $30 \mathrm{sec}$ and extension at $72{ }^{\circ} \mathrm{C}$ for 45 sec. The final extension was achieved at $72^{\circ} \mathrm{C}$ for $10 \mathrm{~min}$.

\section{Analysis of PCR product}

The amplified PCR products were analysed by agarose gel electrophoresis using $2 \%$ agarose containing $0.5 \mu \mathrm{g} / \mathrm{ml}$ ethidium bromide in tris-borate EDTA (TBE) buffer and visualized under UV trans illuminator, as per the method of Sambrookeet al., (1989).

The amplified DNA product was examined by comparison with standard DNA marker (100 bp DNA ladder, Takara dye plus). The image of gel was obtained using gel documentation system (Alpha Imager). PCR amplicons of the positive samples were purified as per the protocols recommended by MACHEREYNAGEL NucleoSpin Gel and PCR Clean-UP. 


\section{Nucleotide Sequencing, Phylogenetic Analysis and Accession number}

The PCR products of $M$. gallisepticum were purified and sent for sequencing at DNA sequencing facility of Department of Animal Biotechnology, College of Veterinary Sciences, LUVAS, Hisar. The nucleotide sequencing was done by Automated DNA sequencer, Applied Biosystem 3130 XL Genetic analyser in both directions.

The sequences were trimmed and analysed in MeAlign program (Lasergene, DNASTAR). The sequences were aligned by ClustalW software. The nucleotide sequences obtained for Mycoplasma gallisepticum (16 to $23 \mathrm{~S}$ rRNA) by using Mega 7.0.26 (Molecular Evolutionary Genetic Analysis). They were aligned by ClustalW. The phylogenetic tree was made by maximum likelihood tree using 1000 bootstrap value. The sequences reported in this article have been deposited in the GenBank database under accession number MK922122.

\section{Results and Discussion}

$16 / 100$ (16\%) samples were found to be positive for Mycoplasma gallisepticum by Polymerase Chain Reaction.

\section{Mycoplasma gallisepticum 16S-23S rRNA intergenic spacer region}

Phylogenetic analysis carried out by using the sequence of the present study with 19 other sequences (Table 2) and is depicted in Figure 2.

The sequences were in the same clad along with other sequence reported from India (KX759108) and other countries Japan (AB098504), USA (KC247863, AY744942, JN935873). The sequences from other countries were present in different clads including Brazil (KT824823, KJ019166), Egypt (GU357708), Germany (KP710079), South Africa (MF196171) and USA (KJ468424, KJ468432). It was very divergent from South Africa (KY362223).

Fig.1 Agarose gel showing Mycoplasma gallisepticum from poultry field samples. M- $100 \mathrm{bp}$ ladder; 1-8- samples; 9- negative control.

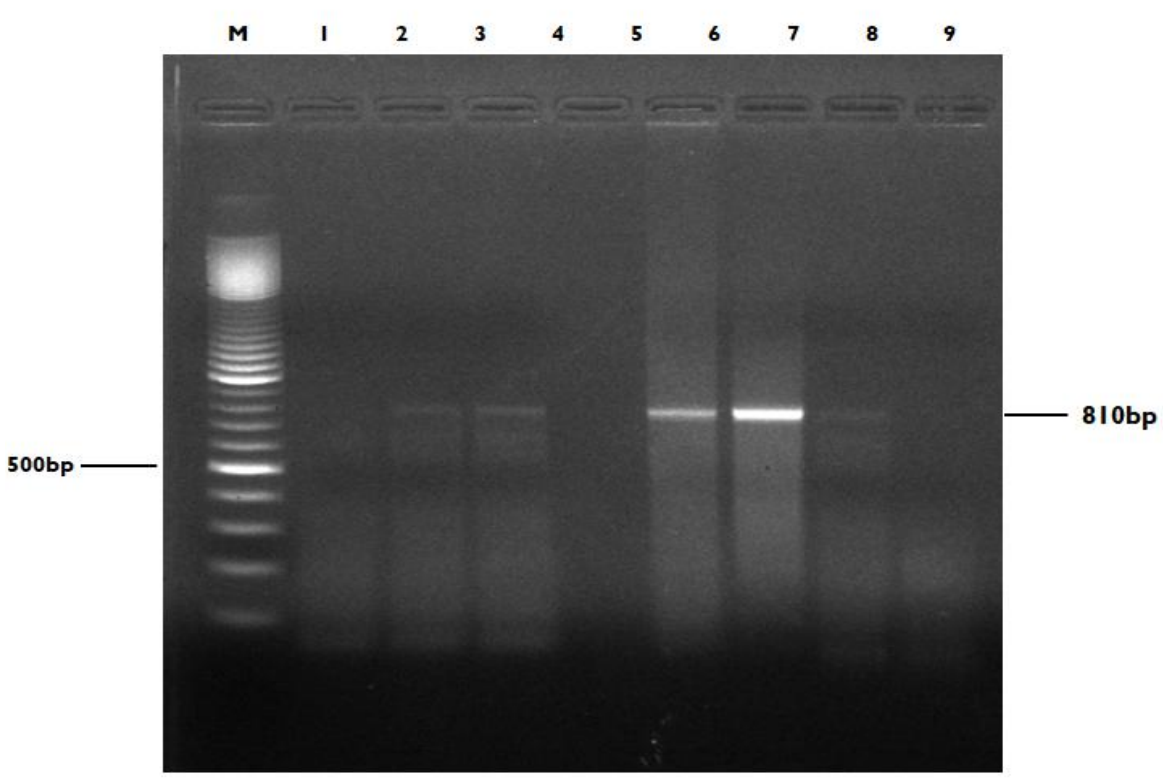


Fig.2 Phylogenetic tree based on partial nucleotide sequences of 16S-23S rRNA IGSR gene of Mycoplasma gallisepticum. Phylogenetic tree constructed by the maximum likelihood tree method using 1000 bootstrap replicates value in Mega7.0 software.

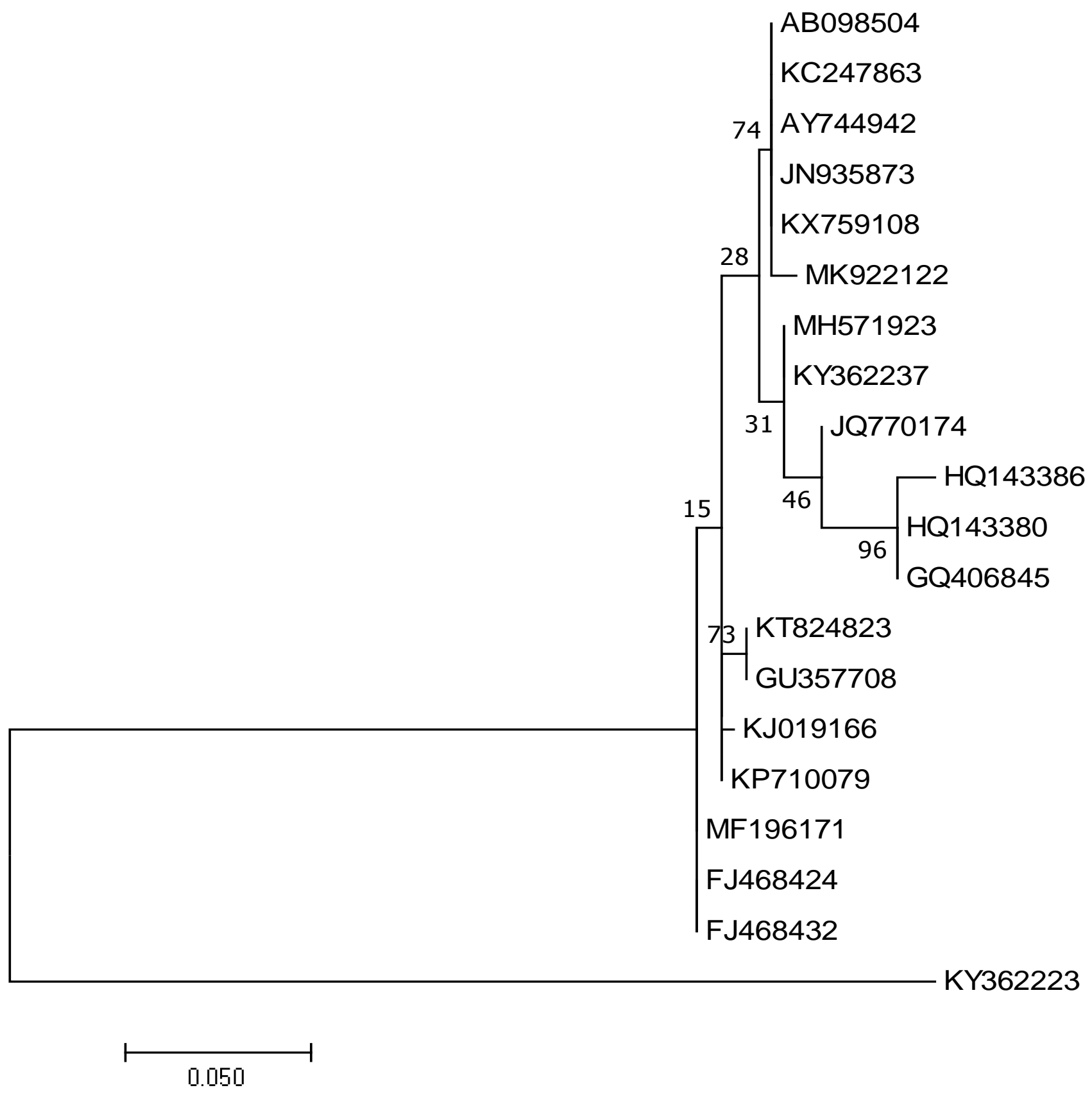


Table.1 Accession number of various isolates obtained for Mycoplasma gallisepticum

\begin{tabular}{|l|l|l|l|}
\hline Accession number & Year & Country & Strain/Host \\
\hline MK922122 & 2019 & Haryana, India & Lungs, trachea, air sacs \\
\hline AB098504 & 2002 & Japan & PG31 \\
\hline KC247863 & 2012 & USA & USA/R/CK60 \\
\hline AY744942 & 2004 & USA & ATCC19610 \\
\hline JN935873 & 2011 & Rockville, USA & PG31CX95 \\
\hline KX759108 & 2016 & Haryana, India & PT-89 \\
\hline MH571923 & 2018 & South Africa & B2777-15A-8 \\
\hline KY362237 & 2016 & South Africa & ZA_MGB1932_15 \\
\hline JQ770174 & 2012 & Australia & 6-85 \\
\hline HQ143386 & 2010 & Jordan & OR/83/CKB \\
\hline HQ143380 & 2010 & Egypt & EGY/67240/CK08 \\
\hline GQ406845 & 2009 & Egypt & RabE2-09 \\
\hline KT824823 & 2015 & Brazil & BRA/UFF/LSA020 \\
\hline GU357708 & 2008 & Egypt & RabE4-08 \\
\hline KJ019166 & 2011 & Brazil & 2011/UFMG1 \\
\hline KP710079 & 2011 & Germany & 2038/11/CK \\
\hline MF196171 & 2017 & South Africa & B878-14-M2_157 \\
\hline KJ468424 & 2014 & USA & LVT 9815 \\
\hline KJ468432 & 2014 & USA & LVT 9815 \\
\hline KY362223 & 2016 & South Africa & ZA_MG B642_08 \\
\hline
\end{tabular}

\section{References}

Ahmad, A., Rabbani, M., Yaqoob, T., Ahmad, A., Shabbir M.Z. and Akhtar., F. 2008. Status of IGg antibodies against Mycoplasma gallisepticum in nonvaccinated commercial poultry breeder flocks. J. Anim. Pl. Sci.18: 2-3.

Charlton, B.R., Bermudez, A.J., Boulianne, M., Eckroade, R.J., Jeffrey, J.S., Newman, L.J., Sander, J.E. and Wakenell, P.S. In: Charlton BR, editor. Avian disease manual. Kennett Square, Pennsylvania, USA: American Association of Avian Pathologists; 1996. p.115-25

Dodd, S. (1905). Epizootic pneumo-enteritis of turkey. J Comp Pathol. Ther. 18:239-245.

Karthik k, Bharathi R, Mahaprabhu R,Manimaran, K. andShoba, K.
(2018). Chronic respiratory disease outbreak in an organized native chicken farm. Journal of Dairy, Veterinary \& Animal Research. 7(3): 79-82.

Raviv, Z., Callison, S.N., Ferguson-Noel, Laibinis, V., Wooten, $\mathrm{R}$ and Kleven, S.H. (2007). The Mycoplasma gallisepticum 16S-23S rRNA Intergenic Spacer Region Sequence as a Novel Tool for Epizootiological Studies. Avian diseases. 51:555-560.

Sambrook, J., Fritsch, E.F. and Maniatis. (1989). In: Molecular cloning , a laboratory manual. Second edition. Cold Spring Harbor Laboratory Press.

Sarkar, S.K., Rahman ,M.B., Rahman, M., Amin, K.M.R., Khan, M.F.R. and Rahman, M.M. (2005). Seroprevalence of Mycoplasma gallisepticum infection in chickens in 
model breeder poultry farms of Bangladesh. International Journal of Poultry Science.4(1): 32-35.

Singh, N., Shukla, S. and Sharma, V. (2016). Detection of Anti Mycoplasma gallisepticum Antibodies in Different Age Group of Chicken by Enzyme Linked Immunosorbant Assay. Journal of Animal Research.6(1):49-51.

Stipkovits, L., Glavits, R., Palfi, V., Beres, A., Egyed, L., Denes, B., Somogyi, M. and Szathmary, S. (2012). Pathologic lesions caused by coinfection of Mycoplasma gallisepticum and H3N8 low pathogenic avian influenza virus in chickens. Vet. Pathol. 49(2): 273283.

Talha AFSM (2003). Investigation on the prevalence of Mycoplasma gallisepticum in village chickens and possibility of establishing Mycoplasma gallisepticum free flocks and significance Mycoplasma gallisepticum of different production parameters in layer chickens in Bangladesh. M.Sc. Thesis, Department of Veterinary Microbiology, the Royal Veterinary and Agricultural University, Denmark and Department of Pathology, Bangladesh Agricultural University, Mymensing, Bangladesh.

Tomar, P., Singh, Y., Mahajan, N.K., Jindal, N. and Singh, M. (2017). Molecular detection of avian mycoplasmosis in poultry affected with respiratory problems in Haryana. Int. J.Curr.Microbiol. App. Sci. 6(6):21552162

Yamamoto R. Mycoplasma meleagridis infection. In: Calnek BW, Burnes HJ, Beard CW, Yoder Jr. HW, editors. Diseases of poultry. Ames, Iowa, USA. Ames: Iowa State University Press; 1991. p.212- 23.

\section{How to cite this article:}

Vaishali, Davinder Singh and Renu Gupta. 2020. Molecular and Phylogenetic Analysis of Mycoplasma gallisepticum in Haryana, India. Int.J.Curr.Microbiol.App.Sci. 9(01): 2518-2523. doi: https://doi.org/10.20546/ijcmas.2020.901.286 